\title{
Science|Environment|Health - the emergence of a new pedagogy of complex living systems
}

\author{
Albert Zeyer ${ }^{1 *}$ (D) and Justin Dillon ${ }^{2}$
}

\begin{abstract}
Science|Environment|Health $(\mathrm{S}|\mathrm{E}| \mathrm{H})$ is an emerging science pedagogy for complex living systems. The name highlights a situation of mutual benefit between science education, environmental education and health education. The paper discusses a range of topics from the curriculum-focused origin of the $\mathrm{S}|\mathrm{E}| \mathrm{H}$ movement to the issues that concern $\mathrm{S}|\mathrm{E}| \mathrm{H}$ researchers today. These include, among others, the role of scientific knowledge in $\mathrm{S}|\mathrm{E}| \mathrm{H}$ decision making, medicine education as a paradigmatic example of $\mathrm{S}|\mathrm{E}| \mathrm{H}$, complexity in $\mathrm{S}|\mathrm{E}| \mathrm{H}$ issues, the role of empathy in $\mathrm{S}|\mathrm{E}| \mathrm{H}$, and the tension between societal and individual responsibility. In conclusion, it is argued that two insights are essential for current $\mathrm{S}|\mathrm{E}| \mathrm{H}$ work. First, living systems can be understood both in causal and empathetic terms, which makes $S|E| H$ a powerful 'science for all' approach. Second, in living systems, there is always a trade-off between predictability and homeostasis. This brings $S|E| H$ in a natural antagonism - but not in opposition - to STEM approaches.
\end{abstract}

Keywords: Environmental education, Health education, Medicine education, Socio-scientific issues, Interdisciplinarity

\section{Introduction}

The label Science|Environment|Health (Dillon, 2012) is not meant to suggest that health and environmental education should be swallowed up by science education. Rather, there is a role for both beyond a reimagined science education. The label highlights a situation of mutual benefit between science education, environmental education and health education, three educational dimensions that have yet to be established in a transdisciplinary dialogue (Zeyer \& Dillon, 2014, p.1409).

The concept of Science|Environment|Health emerged from an international conference on the role of environment and health in science education held in 2012. It embraces the idea of an intrinsic win-win situation between science, environmental, and health education. In fact, on the one hand, important studies such as PISA (e.g., Bybee, 2012), ROSE (The Relevance of Science

\footnotetext{
*Correspondence: albert.zeyer@phlu.ch

${ }^{1}$ University of Teacher Education Lucerne, Pfistergasse 20, Postfach 7660,

$\mathrm{CH}-6000$ Luzern 7, Switzerland

Full list of author information is available at the end of the article
}

Education study, Schreiner \& Sjøberg, 2004), and Haste's investigation of students' values and beliefs in relation to science and technology (Haste, 2004), have all identified that environmental and health issues were among those contexts which interest students, and particularly girls, most.

On the other hand, at the time of the 2012 conference, environmental education had already enjoyed a long connection with science education (Gough, 2007). As to the role of health education in science education, the situation was less clear (e.g., Harrison, 2005). Yet, a few studies had already suggested that students would benefit from a deeper conceptual understanding of the science behind environmental and, particularly, health issues (Keselman, Kaufman, \& Patel, 2004; Zeyer \& Odermatt, 2009). There seemed to be a situation of mutual benefit that had been underestimated until then (e.g., Zeyer, 2012).

Figure 1 shows a conceptualization that might reflect the degree of interdisciplinarity between science, environmental, and health education found today in many school curricula. Here, the overlap of all three of the Science|Environment|Health triad is very limited (Adams et al., 2018). Many students do not learn 


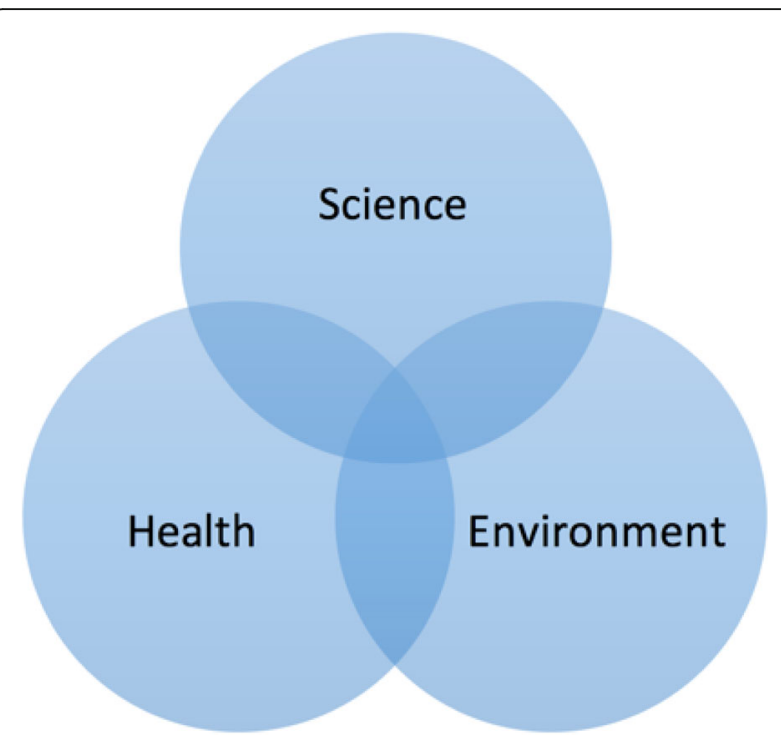

Fig. 1 The traditional nature of Science|Environment|Health in the school curriculum

enough about two major areas of their lives in their studies of science in school. Indeed, there is some evidence that young people learn much of what they know about health and environmental issues from the Internet or from their friends, families and doctors (see, for example, Kennedy, Basket, \& Sheedy, 2011).

Figure 2 shows a more radical $S|E| H$ perspective that, we would argue, more adequately reflects the lived experience of most of today's citizens, and the win-win situation between those three fields of education. The intersection of the three circles is much larger. The

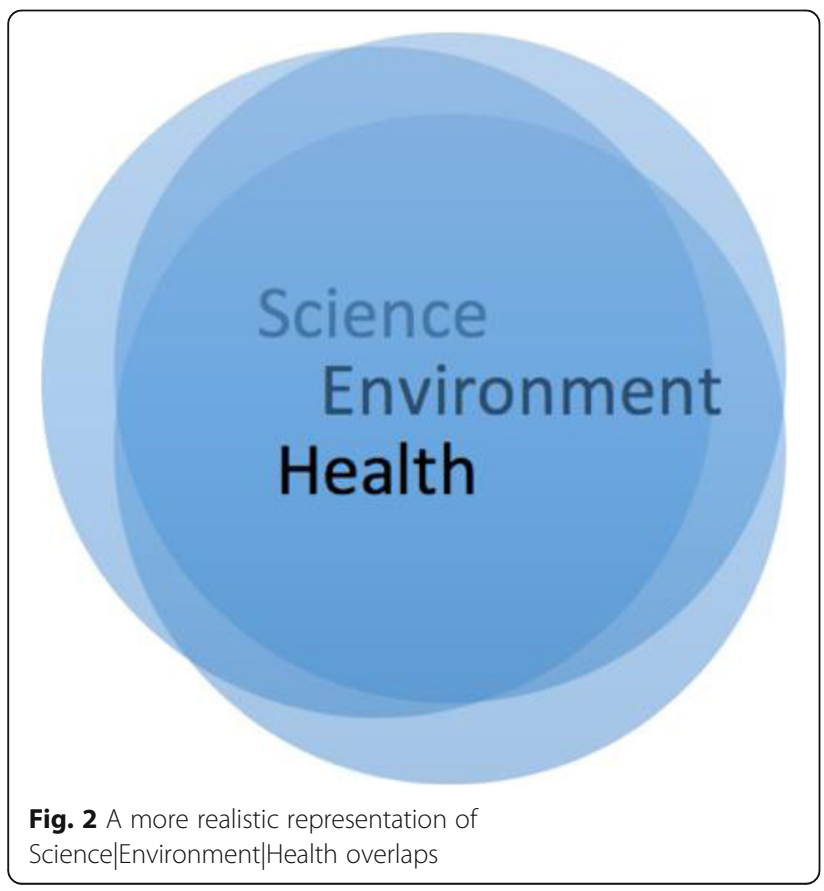

more opaque colouring of the science circle wants to indicate that, in terms of psychological distance (e.g., Liberman \& Trope, 2014), health and the environment are two critical dimensions of the real world whereas science, though it helps to explain much about us and our planet, is one step removed. From a curriculum point of view, we would argue, health and the environment provide key contexts that can show both the value and the limitations of the scientific endeavour (Zeyer \& Dillon, 2019).

We call Science|Environment|Health a science pedagogy - a method and practice of science teaching - because it is deeply rooted in post-World War II attempts to reform traditional school curricula, particularly in the Science Technology Society movement and in Culture Studies of Science (for an overview see Aikenhead, 2006), and because it has intimate links to the socioscientific issues (SSI) movement of the last 15 years (differences and new perspectives will be discussed throughout this paper).

The new $\mathrm{S}|\mathrm{E}| \mathrm{H}$ approach found much interest in the science education community which led to the foundation of the special interest group (SIG) Science|Environment|Health of the European Science Education Association (ESERA) conference in 2014. The SIG mission statement described the aim of the group as forming a broad consensus that health and environment should be included more intentionally and prominently in science education than they are at present, and to articulate arguments and aspects supporting this claim.

The key objective of the SIG is to establish a network of researchers in Europe and beyond in order to foster research on a new $\mathrm{S}|\mathrm{E}| \mathrm{H}$ pedagogy, and to coordinate initiatives for implementing it in school and raising awareness on a societal and political level. Since 2014, the SIG has inspired new research and developments, and it has attracted a growing research community of great diversity.

\section{Insights and findings from the work of the Science|Environment|Health field}

We move on now to present some insights and findings of this new and burgeoning field of science pedagogy. We provide an overview of recent European $\mathrm{S}|\mathrm{E}| \mathrm{H}$ research activities across various research strands and reflect on the resulting findings which are opening up new roads for further research.

\section{The role of scientific knowledge in Science|Environment|Health}

$\mathrm{S}|\mathrm{E}| \mathrm{H}$ is not environmental and health education under the mantle of science education. But what is it, then? Members of the SIG felt from the beginning that the status of scientific knowledge in the field 
would be important. $\mathrm{S}|\mathrm{E}| \mathrm{H}$ is a science pedagogy, i.e., it is first and foremost concerned with science in education. Environmental and health issues are seen as attractive contexts for teaching and learning science, and not the other way round.

A historical perspective helps to estimate the importance of this statement (e.g., Zeyer, 2012). Indeed, in health education, for decades, a construed antinomy between a salutogenetic and a pathogenetic approach to health had led to a critical view of bio-medical health knowledge as reductionist, mechanistic, and allopathic (for example Hurrelmann, Klotz, \& Haisch, 2004). Such criticism had opened a gap between the culture of science and the culture of health promotion, which largely resulted in a neglect of the role of bio-medical knowledge in health promotion and prevention (e.g., Hafen, 2007). So, if there had really to result a mutual benefit between science, environmental and health education, $\mathrm{S}|\mathrm{E}| \mathrm{H}$ had to bridge these reservations. In the same way, environment as part of $\mathrm{S}|\mathrm{E}| \mathrm{H}$ could not be interpreted on a purely value driven behavioural level but had to offer a substantial role to scientific knowledge on environmental considerations.

At this time, several $\mathrm{S}|\mathrm{E}| \mathrm{H}$ researchers use decision making to investigate the role of scientific knowledge. Already in 2004, Keselman, Kaufman and Patel had shown that conceptual scientific knowledge could help students to unmask common myths about HIV prevention and therapy (Keselman et al., 2004). Recently, Zeyer and Sidler investigated the situation with the vaccination against the Human Papilloma Virus (Zeyer \& Sidler, 2015). Again, they were able to identify some 'vaccination myths' that hindered young adults from deciding in favour of HPV vaccination. One of these myths was that immune agents in the HPV vaccine could mutate and become virulent again and thus could initiate the illness they were supposed to prevent. Keselman and Zeyer were able to show that a short text addressing this myth was able to significantly influence hesitant young adults' decision making about HPV vaccination (Keselman \& Zeyer, 2018).

Zeyer (2012) made a first attempt to theoretically frame the role of knowledge in a model based on Gräsel's model of environmental competency (Gräsel, 1999). The result found its way into a careful and encompassing account of decision-making models in health and environment contexts by Arnold, who proposed an integrated model of decision-making in health contexts (Arnold, 2018). She argues that, in order to make decision models fruitful for science education, scientific knowledge should be integrated into the decision-making process. Arnold's model relies upon expectancy-value pairs (Fishbein \& Ajzen, 1975) and can be seen as a bridge between Robert's
Vision I and Vision II of scientific literacy, a conceptual framework that science for all theorists often draw on (Roberts, 2007). Arnold and colleagues used this decision model to investigate the role of diabetes knowledge in decisions about sugar consummation. Heuckmann, Hammann, and Asshoff (2018) also use expectancy-value pairs for investigating teachers beliefs and concerns about cancer education, another salient example of a medicine context for teaching science.

\section{Medicine education}

Much of the new $\mathrm{S}|\mathrm{E}| \mathrm{H}$ research is concerned with medical rather than health contexts. Therefore, in the $\mathrm{S}|\mathrm{E}| \mathrm{H}$ field, the insight has grown that the relation between medicine and science may be an even more powerful and relatively unexploited resource for science education than the relation between health and science (e.g., Keselman et al., 2018).

It is in this context that the term medicine education finds growing interest among science education researchers. To our knowledge, the term was coined by the Finnish researchers Siitonen, Hämeen-Anttila, Keinonen, and Vainio (2014) and, originally, was concerned with the rational use of medical drugs. Finnish science teachers are substantially engaged in teaching medicine education, but their efforts still seem to be closer to traditional health education than to a decisively sciencerelated approach to health and disease.

In $\mathrm{S}|\mathrm{E}| \mathrm{H}$, we see medicine education as the pedagogical field that prepares future citizens for patientcentred medicine. In this way, health and medicine education are two sides of the same coin and medicine education fits well into the field. Indeed, it contributes much to the targeted win-win situation. Medicine is a treasure trove for interdisciplinary scientific contexts that do motivate many students to learn science (Zeyer, 2006). Conversely, science education contributes naturally and straight-forwardly to patient education. There is much at stake. For example, Faria, Freire, Baptista and Galvão investigated this approach in the context of the role of hormonal changes during the female menopause, which are a risk factor for cardiovascular diseases (Faria, Freire, Baptista, \& Galvão, 2014). Their results revealed that many students had difficulties in using scientific knowledge in argumentation and used 'hybrid' talk that mixed scientific concepts and common sense knowledge in a misleading way.

Another carefully designed study that recently emerged from the $\mathrm{S}|\mathrm{E}| \mathrm{H}$ field investigated the knowledge of Austrian students about viruses and antibiotics (Simon, Enzinger, \& Fink, 2017). The authors found that students' (even undergraduate biology students') conceptual knowledge about viruses was far from deep enough to dismantle 
myths about antibiotics. Future developments will combine the $S|E| H$ research about decision making on antibiotics with this basal study about virus knowledge, a highly topical issue (e.g., World Health Organisation, 2018).

An interesting question in this context is if $\mathrm{S}|\mathrm{E}| \mathrm{H}$ issues are just special examples of socio-scientific issues (SSI). The answer is ambivalent, as particularly medicine contexts illustrate. Many practical medicine contexts are in fact good examples of SSI, i.e. "open-ended, illstructured, debatable problems subject to multiple perspectives and solutions" (Sadler \& Zeidler, 2005, p. 115).

On the other hand, the clinical approach in medicine is, in principle, not open-ended, ill-structured and debatable, but usually very much identified with scientific method. Its eminently systematic claim is underlined by the ideal of evidence based medicine - the conscientious, explicit, judicious and reasonable use of modern, 'best' evidence in making decisions about the care of individual patients (Masic, Miokovic, \& Muhamedagic, 2008).

All in all, medicine issues saliently illustrate how $\mathrm{S}|\mathrm{E}| \mathrm{H}$ issues often combine, in a highly sophisticated way, characteristics of classical science with typical SSI aspects. On the one hand, highly systematic questions are scientifically theorized, empirically investigated, methodically implemented, and statistically evaluated. On the other hand, patients and doctors are confronted with "a variety of social dilemmas with conceptual, procedural, or technological associations with science, [which] typically involve the products or processes of science and create social debate or controversy" (Sadler \& Zeidler, 2005, p. 112).

\section{Complexity and Science|Environment|Health}

Fensham (2012) suggested introducing complexity into science education. Since that call, it has become a critical feature of $S|E| H$ (e.g., Zeyer et al., 2019). Complexity theory distinguishes between four types of systems. Ordered ('linear') systems are simple or complicated; complex ('non-linear') systems are complex or chaotic. The resulting $2 \times 2$ matrix has been called the Cynefin

Table 1 The Cynefin Framework (Zeyer et al., 2019, adapted from Snowden and Boone, 2007, and Fensham 2012)

\begin{tabular}{lc}
\hline Ordered systems & Complex systems \\
\hline Simple contexts & Complex contexts \\
• Static linear systems & • Non-linear Systems \\
• 'Fully' predictable & • Not predictable \\
• Example: Plant taxonomy & • Example: Cardiovascular system \\
Complicated contexts & Chaotic contexts \\
• Dynamic linear systems & • Non-linear or 'non' systems \\
• Highly predictable & - 'Fully' unpredictable \\
• Example: Newton mechanics & • Example: Stock markets \\
\hline
\end{tabular}

framework (Table 1), which was originally developed in economics (Snowden \& Boone, 2007).

Fensham suggested introducing the Cynefin framework into science education and made clear that noncomplex contexts, particularly simple ones, are still much too dominant in the field. He observed that all the great challenges of this century are highly complex and concluded that $\mathrm{S}|\mathrm{E}| \mathrm{H}$ issues in their full-blown complexity should be much more prominently represented in science teaching. Similar arguments from other important authors can be found in the science education literature (e.g., Abd-El-Khalick \& Zeidler, 2015).

The US Next Generation Science Standards identify 'systems and systems models' as a crosscutting concept (NGSS Lead States, 2013), and the study of complex systems has been highlighted in recent science education policy in the United States, as an encompassing review of empirical studies of teaching and learning about complex systems underlines (Yoon, Goh, \& Park, 2017). This review also reveals a need for further research particularly on the essential features of complex systems content.

From a complexity point of view, living systems are complex self-organizing dissipative systems (e.g., Prigogine, 1981). Important to such phenomena are "the dynamics of non-linear interactions (where responses of a system can be much larger than the stimulus) and autocatalytic cycles (reaction sequences that are closed on themselves and in which a larger quantity of one or more starting materials is made through the processes)" (Weber, 2015, p. 5). Notice, that this concept is formulated entirely within the scientific paradigm. In particular, it does not refer to anthropomorphic concepts of animals and plants, though there might be good argument for braking this taboo (e.g., Zohar \& Ginosar, 1998). Complex living systems in the above defined, scientific sense are of core interest in a new Science|Environment|Health pedagogy.

The scientifically delicate relation between prognosis and unpredictability in complex living systems is a challenge to environmental, health and medicine education. For example, many people suffer from damage caused by unhealthy behaviour, but not all. Some, for example, may be chain smokers and nevertheless live a long and healthy life. We call this the Churchill effect (Zeyer et al., 2019). Science (and science education) may explain this tension, but only if it relaxes from its notorious craving for generality, as the philosopher Ludwig Wittgenstein called it (Wittgenstein, 1958).

Relaxing from generality calls for new approaches to teaching and particularly to assessment in science education. One $\mathrm{S}|\mathrm{E}| \mathrm{H}$ group (Benninghaus, Mühling, Kremer, \& Sprenger, 2019) uses the mystery method to visualise student thinking about complex systems. The method was designed to help students to create influence 
diagrams about systems, i.e., the students receive several information cards with facts and have to connect them to a diagram to visualize influences (Leat \& Nichols, 2000). The complexity of an issue is mirrored in the fact that the resulting diagrams can differ widely from each other because complex issues refuse to give single solutions. In order to assess the students' diagrams, the group used relatedness judgements by asking experts about the bilateral information card connections.

Note that relaxing from generality does not mean scientific arbitrariness. Though the diagrams resulting from the mystery approach can differ widely, the facts provided by the cards are still scientific facts, and the connections between the cards still represent empirically verified relations. Both have to be understood and interpreted in correct scientific terms.

\section{The role of empathy in complex}

\section{Science|Environment|Health contexts}

In $\mathrm{S}|\mathrm{E}| \mathrm{H}$ contexts, the human factor is often an important reason for complexity. The human mind is paradigmatically complex and, often, purely scientific intervention is not viable because of human disposition. In medicine, for example, this issue is well known and captured in the shared decision-making model, which is probably today's most popular model in patient-centred medicine (Elwyn et al., 2012). Shared decision-making has been defined as an approach where clinicians and patients share the best available evidence when faced with the task of making decisions. However, patients are also supported to consider personal options and to achieve informed preferences (Elwyn et al., 2010). This description has also been condensed to the formula of getting both evidence and preferences into health care (Barratt, 2008, p. 407). Actually, this is more than a nice label, as Elwyn et al.'s (2017) article in the influential British Medical Journal points out:

Instead of assuming that decisions should be guided by scientific consensus about effectiveness, shared decision making proposes that informed preferences-by which is meant what matters to patients and families-should play a major role in decision making processes. Shared decision making is more than being attentive to patients' needs or concerns: it represents an important shift in the roles of both patients and clinicians. (p. 1)

Conversely, research has shown that the lack of addressing empathic cognition in science classrooms contributes to low motivation among many students, particularly females (e.g., Zeyer, 2017). Therefore, it has been suggested that there are benefits from the intrinsic involvement of the human factor in $\mathrm{S}|\mathrm{E}| \mathrm{H}$ issues in order to 'include empathy more seriously and consistently, but with due caution, in science learning' (Zeyer \& Dillon, 2019, p. 297). Empathising in $S|E| H$ contexts is then not only tolerated as an attracting factor for empathisers but it is actually essential for wise decision-making. When opting for this opportunity, the danger is to forget about systematic science. How to balance both systematic and empathic aspects of a context is a typical research question of the $\mathrm{S}|\mathrm{E}| \mathrm{H}$ field and may draw from research on reflective equilibrium in applied ethics (e.g., Daniels, 1979). This approach is supported by the concept of informal reasoning in SSI, which includes three patterns: rationalistic, emotive, and intuitive informal reasoning (Sadler, 2004). Emotive informal reasoning involves a care perspective and empathy for other people involved in the situation.

Dual-process theories might here also be helpful to future research (e.g., Evans \& Stanovich, 2013). They have been established during the last 30 years, largely independently, in four separate areas of psychology: learning, reasoning, social cognition and decision making. According to dual-process theories there are two types of mental processes that underlie decision-making (Schlosser, 2015). Type 1 processes, often labelled as intuitive, are typically characterized as automatic and effortless. The decision task is construed as personal, conversational, socialized and highly contextual. Conversely, Type 2 processes, often called reflective or systematic, are conscious, deliberate, and rule-based. Type 2 construes decision tasks as depersonalized, asocial and decontextualized.

In this framework, decision making is seen as the result of the interaction of Type 1 and Type 2 processing. Though much researched and even more debated, there is, so far, no commonly accepted view on how this interaction works (ibid.). Further $\mathrm{S}|\mathrm{E}| \mathrm{H}$ research may well contribute to clarifying these issues.

\section{Informed citizenship and personal responsibility}

Some $S|E| H$ researchers emphasise that health and sustainable development should be considered as both science and social science issues. Health and sustainable development involve, as do other socio-scientific issues, both descriptive knowledge and normative values (Byrne, Ideland, Malmberg, \& Grace, 2014; Ekborg, Ideland, \& Malmberg, 2017). Consequently, students need to understand these issues as scientific phenomenon as well as individual and societal concerns with different possible solutions.

An interesting approach that shows some similarities has been proposed by Sjöström and colleagues (Sjöström \& Talanquer, 2018). Referring to the old humanistic concept of Bildung, they suggest what they call an ecoreflective approach: 
In eco-reflexive Bildung the socio-political dimension is particularly important, in conjunction with both humanism and the vulnerability of the eco- systems [...]. Just like many Eastern philosophies, it integrates cognitive and affective domains. It involves taking a critical stance towards the risk society, seeking to understand the complexity of life and society and their interactions, and assuming responsibility for individual and collective actions towards socio-ecojustice and global sustainability. (p. 18)

Malmberg and his colleagues, in contrast, discuss the individual and the societal/political as two conflicting levels. In their view, the individual perspective is (mis-)used for instrumentalising students. They call this, not without some cynicism, the making of the health- and eco-certified citizen (Hillbur, Ideland, \& Malmberg, 2016). Individuals are seen as being responsible for their own health and for sustainability which is often associated with attributions such as individualization, responsibilization and, within the context of health, healthism.

Yet, as Hillbur et al. (2016) point out, in this way, health and environmental concerns are de-politicised because they lack key components of politics such as collective decision-making and responsibility. Democratic political approaches, they say, would mean the opposite. Health and sustainability would then be construed as political issues, i.e., as issues that are subject to democratic decisions that affect citizens and society as a whole.

Malmberg and his colleagues claim that, over the past 30 years, there has been a shift from democratic politics to individual responsibility within a wide range of areas. They call this shift the 'paradox of responsibility' (Malmberg \& Urbas, 2018). This paradox appears when health and sustainability problems are individualized (de-politicized) and thereby not seen as a primary concern for democratic politics. Responsibility for health issues such as obesity or smoking, but also for climate change, is placed on the individual rather than on the societal and political level even though research shows that the problems are caused by societal factors and therefore need political solutions.

Zeyer and colleagues have shown in their research that this paradox of responsibility can entail emotional problems for the certified eco-kid. They analysed drawings from more than 400 children. Primary school students expressed their touching naïve hopes for an ecological future where humans live in harmony with nature (Zeyer \& Kägi, 2010). At the age of 12 to 13 years, the researchers could observe a sharp change towards hopeless and almost cynical drawings of nature on retreat from the attack of human technology and civilization (Figs. 3 and 4). This change went hand in hand with an emerging post-ecological discourse, characterized by the discursive resource of: 'environmental protection would be very important, but unfortunately is not manageable these days' (Zeyer \& Roth, 2013). The researchers interpreted these changes in terms of a loss of self-efficacy felt by the certified eco-citizen. The paradox of responsibility charges them with a mission they feel they cannot accomplish. The result is an ecodepression (Zeyer \& Roth, 2013).

These problems result from environmental scientism (Zeyer, 2007), a type of science teaching that focuses on environmental and health evidence and tends to neglect the affective needs of the students. Again, there may come some inspiration from patient-centered medicine. The three step model of shared decision making (Elwyn et al., 2017) has been developed to help physicians and patients to find their way between evidence and preference. It starts with choice talk, wherein the importance of respecting individual preferences is underlined and the role of uncertainty in medicine is explained. In a second step, the options talk, options are listed and potential harms and benefits are clarified. The process ends with step 3, the decision talk, wherein preferences are elicited and eventually a decision is made or else deferred.

The three step model of shared decision making may be helpful for teaching medicine contexts in science class rooms and it may also be adapted for SSI in a broader sense and could result in a more general model for science teaching in complex contexts.

\section{Outlook}

There are other ideas and research topics emerging from the field, some of them not yet published. For example, Keselman and colleagues investigate 'fake health news' spread through the Internet and address the role of scientific literacy in this context (Keselman, Arnott Smith, Murcko, \& Kaufman, 2019). A topic that fits with $\mathrm{S}|\mathrm{E}| \mathrm{H}$ in a self-explanatory way is environmental health. A Spanish group led by Olga Mayoral has been attempting to give voice to this important issue in the $\mathrm{S}|\mathrm{E}| \mathrm{H}$ community (Gavidia, Garzón, Talavera, Sendra, \& Mayoral, 2019). Another promising issue are narrative approaches to complexity talk in $\mathrm{S}|\mathrm{E}| \mathrm{H}$ (Fuchs, 2015).

\section{A conceptual outlook}

Last, but not least, living systems have another facet that has not yet come to the surface. So far, in SSI research, complexity has mostly been featured as a source of disorder and uncertainty. This is true also for living systems. However, living systems are also the most impressive examples of the self-organizing power of 


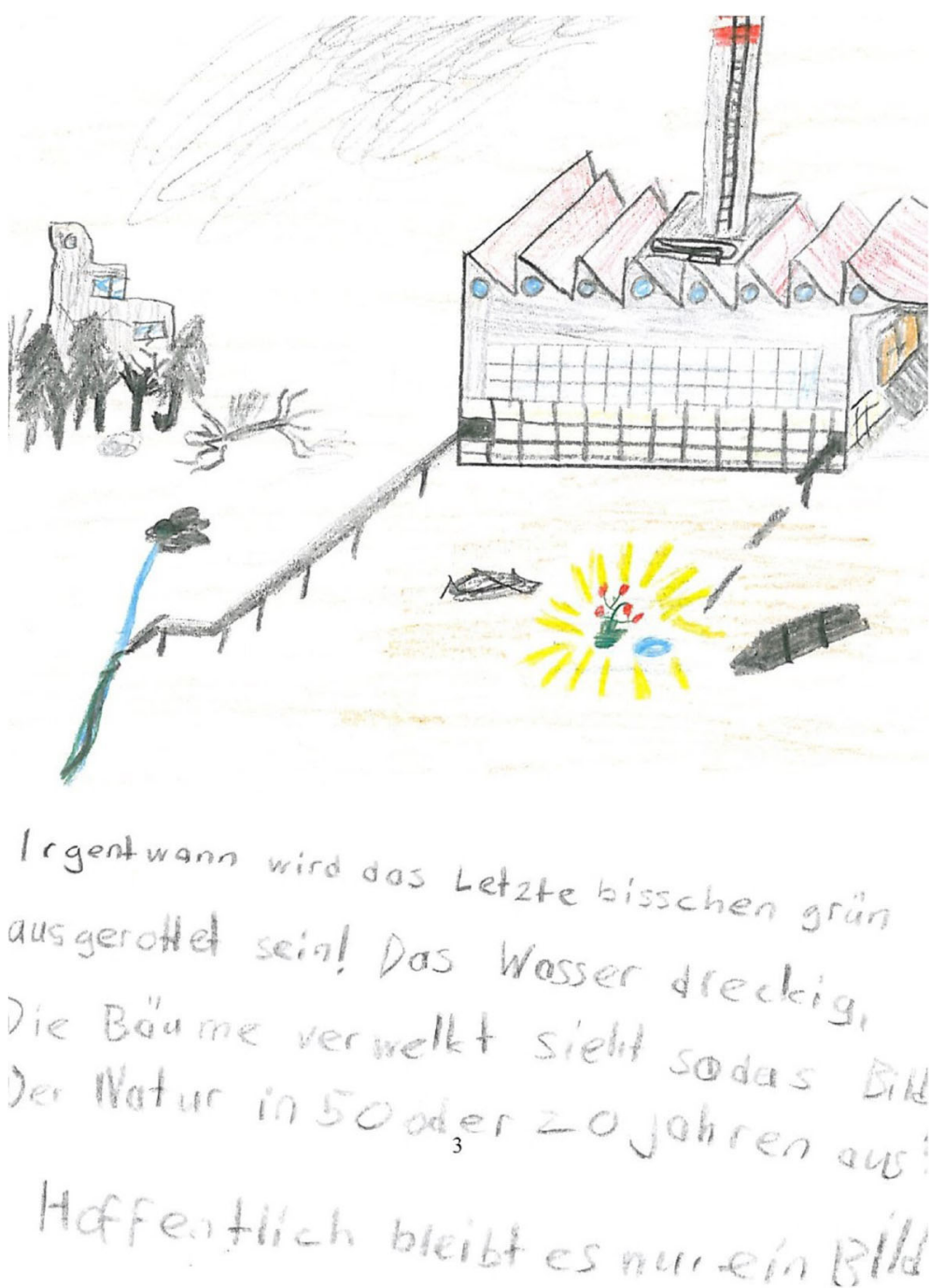

Fig. 3 Example of eco-depression in pictures of 10-to-12-year-old students. "At some point, the last bit of green will be extinct. The water will be dirty. The trees will wilt. The picture shows nature in 50 or 20 years. Hopefully this remains only a picture"

complexity. Already John von Neuman, who was one of the first scientists to use the term "complexity", pointed out that "self-replicating automata" (as he called them) need to show an abundant degree of order - beyond anything that linear systems of "rigid" bodies ever could produce. It was this that he wanted to describe by the term "complexity", and not unpredictability and uncertainty (Von Neumann \& Burks, 1966).

Living systems are self-organized. Non-linear complexity is literally vital to them as it produces dissipative homeostasis - patterns of highest order emerging far from thermodynamic equilibrium, which can be accessed and explained by interdisciplinary science. Conversely, systems that are fully subdued to prediction and control are inherently non-living. There is, to bring it to the point, always a systems theoretical trade-off between life and predictability.
We advocate that Science|Environment|Health is the guardian of this trade-off, and that this point makes $\mathrm{S}|\mathrm{E}| \mathrm{H}$ special and distinct from other movements. The evidence and preference approach in medicine may give a first glimpse how the trade-off may work. The term of evidence describes the scientific, interdisciplinary, prediction guided approach to health and disease. The term of preference evokes the adaptive account of patients' needs and wishes.

In medicine, the evidence part is obviously still much more predominant than the preference part. However, some medical researchers are warning of an overemphasis on evidence (Greenhalgh, Howick, \& Maskrey, 2014). Many interesting questions arise with this. What does it mean in health and environmental contexts generally? How do we help students to understand and apply scientific knowledge in complex 


\section{Wir Menschen nehmen den Tieren zu uUszihen.

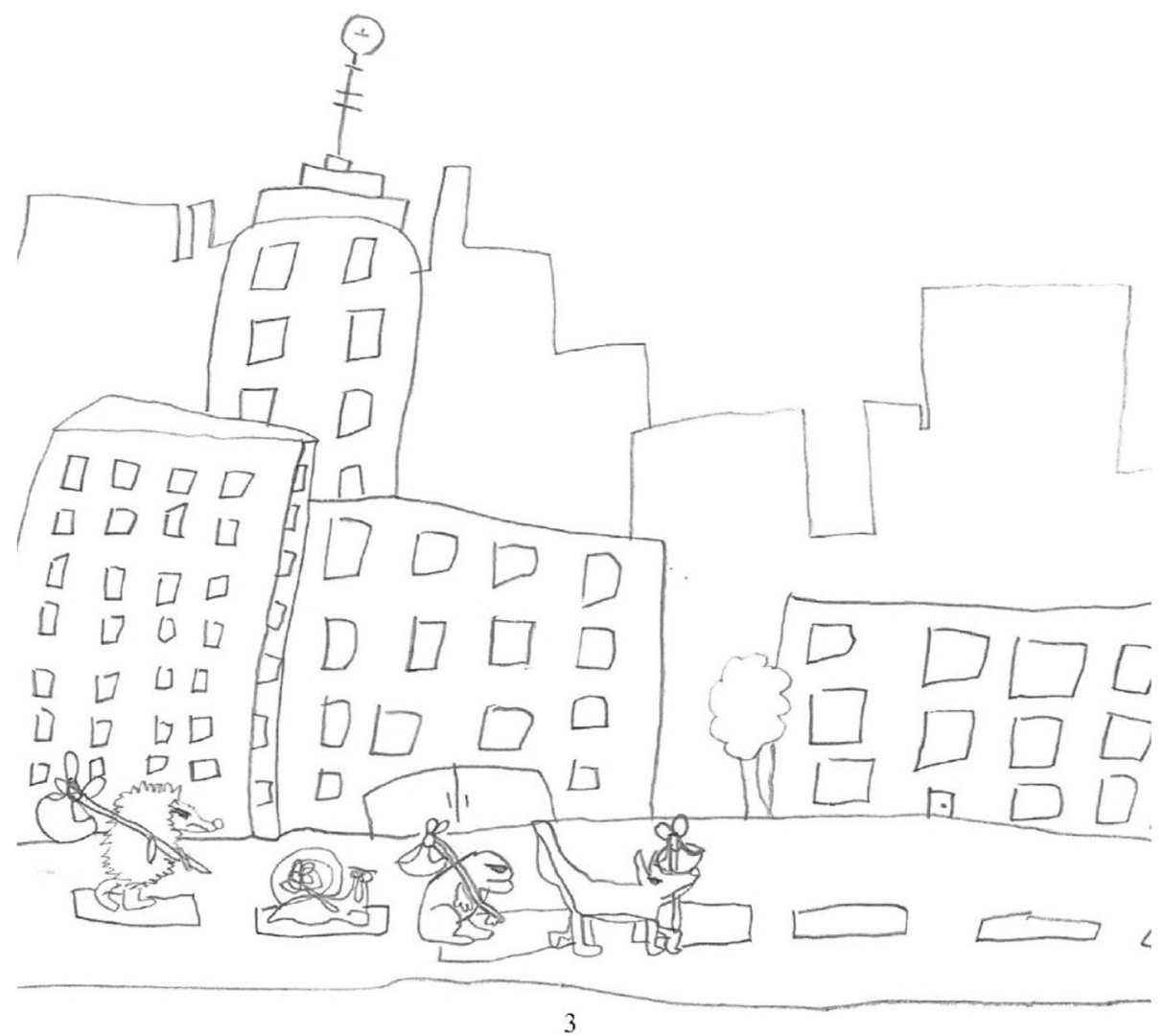

Fig. 4 Example of eco-depression in pictures of 10-to-12-year-old students. "We humans take too much space away from the animals. That's why they have to move out"

real life contexts? What are health literacy and environmental literacy from this point of view, and what are they not? These are fascinating research questions that can and should be tackled in future $\mathrm{S}|\mathrm{E}| \mathrm{H}$ research.

\section{Conclusions}

We have spanned a wide arc from the origins of Science|Environment|Health to the present topics that concern $\mathrm{S}|\mathrm{E}| \mathrm{H}$ researchers. Many facets of research and development have been presented, many open research questions have been sketched out. We showed that many of them link to other strains of interdisciplinary research in science, science education, health and environmental sciences, medicine, psychology, sociology, and also philosophy.
In conclusion, we believe that two aspects have mainly driven recent $\mathrm{S}|\mathrm{E}| \mathrm{H}$ work and will spark future $\mathrm{S}|\mathrm{E}| \mathrm{H}$ activities. Both are rooted in important insights about living systems. The first insight is that complex living systems not only allow for scientific explanation, but also for empathetic understanding (e.g., Hofman, Sharma, \& Watts, 2017). In this way, including $\mathrm{S}|\mathrm{E}| \mathrm{H}$ contexts is a science for all strategy that may foster motivation to learn science of a broad range of students, particularly also of girls (see above the paragraph about empathy in complex $\mathrm{S}|\mathrm{E}| \mathrm{H}$ systems).

The second insight is that, in living systems, there is an intrinsic trade-off between life and predictability (see the outlook section above). A Science|Environment|Health pedagogy that takes this into account 
could grow into the role of an indispensable antagonist to the "T* movements in science education, with Science, Technology, Engineering and Mathematics (STEM) as the newest example. Technology and engineering are focusing on prediction and control, sometimes at high costs for living systems. Students may then experience science as hostile to life and appreciate a counter position which does not draw on moral condemnation but on systems theoretical argumentation for interpretation and adaption.

Future research will investigate the relation between STEM and $\mathrm{S}|\mathrm{E}| \mathrm{H}$. Medicine education again shows that there is no point of construing an antinomy between these equally valuable approaches to science education. Yet: if there is an inevitable trade-off between life and predictability, $\mathrm{S}|\mathrm{E}| \mathrm{H}$ opts for life.

\section{Abbreviations}

ESERA: European Science Education Research Association; PISA: Programme for International Student Assessment; ROSE: Relevance of Science Education; S|E|H: Science|Environment|Health; SIG: Special interest group; SSI: Socioscientific issues; STEM: Science Technology Engineering Mathematics

\section{Acknowledgements}

Not applicable.

\section{Authors' contributions}

JD initiated the article and wrote the section 'Introduction'. AZ wrote the sections 'Insights and findings from the work of the

Science|Environment|Health field', 'Outlook', and 'Conclusions'. Both authors read and approved the final manuscript.

\begin{abstract}
Authors' information
Albert Zeyer is a mathematical physicist and a physician. After working as a science teacher and a children's doctor, and doing educational research at the University of Zurich, he is now head of the science teacher education at Lucerne University of Teacher Education, and a professor of medicine at Bern University of Applied Sciences (Switzerland). His research interests include science education, health/medicine education, and public understanding of science. At the European Science Education Research Association (ESERA) conference, he is a co-chair of strand 9 "Environmental, health and outdoor science education", and a co-coordinator of the Special Interest Group Science|Environment|Health. He is a member of the editorial board of the ESERA Science Education Research Series.

Justin Dillon is professor of science and environmental education at the University of Exeter. Prior to this he was Head of the Graduate School of Education at the University of Bristol from 2014 to 17. He has taught on initial teacher education courses and Master's courses with a focus on teacher development and education management - the subject of his PhD. Justin is the Editor-in-Chief of Studies in Science Education and was President of the European Science Education Research Association from 2007 to 11. His research interests focus on the convergence of science and environmental education.
\end{abstract}

\section{Funding}

The authors received no specific funding for this work.

\section{Availability of data and materials}

Not applicable.

\section{Competing interests}

The authors declare that they have no competing interests.

\section{Author details}

University of Teacher Education Lucerne, Pfistergasse 20, Postfach 7660, $\mathrm{CH}-6000$ Luzern 7, Switzerland. ${ }^{2}$ School of Education, University of Exeter, Exeter, UK.

Received: 25 April 2019 Accepted: 24 October 2019

Published online: 28 November 2019

\section{References}

Abd-El-Khalick, F., \& Zeidler, D. L. (2015). New horizons for the journal of research in science teaching. Journal of Research in Science Teaching, 52(3), 263-267.

Adams, J., Avraamidou, L., Bayram-Jacobs, D., Boujaoude, S., Bryan, L., Christodoulou, A., ... Zembal-Saul, C. (2018). The role of science education in a changing world. Netherlands: Lorentz Center.

Aikenhead, G. S. (2006). Science for everyday life. Evidence-based practice. Teachers College Press. New York and London: Columbia University.

Arnold, J. C. (2018). An integrated model of decision-making in health contexts: The role of science education in health education. International Journal of Science Education, 40(5), 519-537.

Barratt, A. (2008). Evidence based medicine and shared decision making: The challenge of getting both evidence and preferences into health care. Patient Education and Counseling, 73, 407-412.

Benninghaus, J. C., Mühling, A., Kremer, K., \& Sprenger, S. (2019). Complexity in education for sustainable consumption - An educational data mining approach using mysteries. https://doi.org/10.3390/su11030722.

Bybee, R. (2012). Scientific literacy in Environmental and Health Education. In A. Zeyer \& R. Kyburz-Graber (Eds.), Science|Environment|Health. Towards a renewed pedagogy for science education. Dordrecht: Springer.

Byrne, J., Ideland, M., Malmberg, C., \& Grace, M. (2014). Climate change and everyday life: Repertoires children use to negotiate a socio-scientific issue. International Journal of Science Education, 36(9), 1491-1509. https://doi.org/10. 1080/09500693.2014.891159.

Daniels, N. (1979). Reflective equilibrium and theory of acceptance in ethics. The Journal of Philosophy, 76(5), 256-282.

Dillon, J. (2012). Science, environment and health education: Towards a reconceptualisation of their mutual interdependences. In A. Zeyer, \& R. Kyburz-Graber (Eds.), Science|Environment|Health. Towards a renewed pedagogy for science education. Dordrecht: Springer.

Ekborg, M., Ideland, M., \& Malmberg, C. (2017). Science for life - A conceptual framework for construction and analysis of socio-scientific cases. Nordic Studies in Science Education, 5(1), 35-39.

Elwyn, G., Durand, M. A., Song, J., Aarts, J., Barr, P. J., Berger, Z., ... Van der Weijden, T. (2017). A three-talk model for shared decision making: Multistage consultation process. BMJ, 359, j4891.

Elwyn, G., Frosch, D., Thomson, R., Joseph-Williams, N., Lloyd, A., Kinnersley, P., ... Barry, M. (2012). Shared decision making: A model for clinical practice. Journal of General Internal Medicine, 27(10), 1361-1367.

Elwyn, G., Laitner, S., Coulter, A., Walker, E., Watson, P., \& Thomson, R. (2010). Implementing shared decision making in the NHS. BMJ, 341, c5146.

Evans, J., \& Stanovich, K. E. (2013). Dual-process theories of higher cognition: Advancing the debate. Perspectives on Psychological Science, 8(3), 223-241.

Faria, C., Freire, S., Baptista, M., \& Galvão, C. (2014). The construction of a reasoned explanation of a health phenomenon: An analysis of competencies mobilized. International Journal of Science Education, 36(9), 1476-1490.

Fensham, P. J. (2012). Preparing citizens for a complex world: The grand challenge of teaching socio-scientific issues in science education. In Zeyer, \& Kyburz-Graber (Eds.), Science|Environment|Health. Towards a renewed pedagogy for science education. Dordrecht: Springer.

Fishbein, M., \& Ajzen, I. (1975). Belief, attitude, intention and behavior: An introduction to theory and research. Reading: Addison-Wesley Publishing Company.

Fuchs, H. U. (2015). From stories to scientific models and back: Narrative framing in modern macroscopic physics. International Journal of Science Education, 37(5-6), 934-957.

Gavidia, V., Garzón, A., Talavera, M., Sendra, C., \& Mayoral, O. (2019). Alfabetización en salud a través de las competencias. Enseñanza de las ciencias: revista de investigación y experiencias didácticas, 37(2), 0107-0126.

Gough, A. (2007). Beyond convergence: reconstructing science/environmental education from mutual benefit. In ESERA annual conference 2007. Malmö: European Science Education Research Association. 
Gräsel, C. (1999). Die Rolle des Wissens beim Umwelthandeln - oder: Warum Umweltwissen träge ist. Unterrichtswissenschaft, 27(3), 196-212.

Greenhalgh, T., Howick, J., \& Maskrey, N. (2014). Evidence based medicine: A movement in crisis? BMJ, 348, g3725. https://doi.org/10.1136/bmj.g3725.

Hafen, M. (2007). Mythologie der Gesundheit. Zur Integration von Salutogenese und Pathogenese. Heidelberg: Carl Auer Verlag.

Harrison, J. K. (2005). Science Education and Health Education: Locating the Connections. Studies in Science Education (Leeds University), 41(1), 51-90.

Haste, H. (2004). Science in my future: A study of values and beliefs in relation to scienceand technology amongst 11-21 year olds. Nestlé Social Research Programme, Report, 1, 29.

Heuckmann, B., Hammann, M., \& Asshoff, R. (2018). Using the theory of planned behaviour to develop a questionnaire on teachers' beliefs about teaching cancer education. Teaching and Teacher Education, 75, 128-140.

Hillbur, P., Ideland, M., \& Malmberg, C. (2016). Response and responsibility: Fabrications of eco-certified citizens in Swedish curricula 1962-2011e. Journal of Curriculum Studies, 48(3), 238-245.

Hofman, J. M., Sharma, A., \& Watts, D. J. (2017). Prediction and explanation in social systems. Science, 488(February), 486-488.

Hurrelmann, K., Klotz, T., \& Haisch, J. (2004). Einführung: Krankheitsprävention und Gesundheitsförderung. In Lehrbuch Prävention und Gesundheitsförderung, (pp. 11-19). Bern: Verlag Hans Huber.

Kennedy, A., Basket, M., \& Sheedy, K. (2011). Vaccine attitudes, concerns, and information sources reported by parents of young children: Results from the 2009 HealthStyles survey. Pediatrics, 127(Supplement 1), S92-S99.

Keselman, A., Arnott Smith, C., Murcko, A. C., \& Kaufman, D. R. (2019). Evaluating the quality of health information in a changing digital ecosystem. Journal of Medical Internet Research, 21(2), e11129. https://doi.org/10.2196/11129.

Keselman, A., Devetak, I., Enzinger, S. M., Fink, A., Devetak, S. P., Simon, U. K., ... Zeyer, A. (2018). On the value of health and medicine in science education: Notes from a Science|Environment|Health SIG symposium. In O. Finlayson, E. McLoughlin, S. Erduran, \& P. Childs (Eds.), Proceedings of the ESERA 2017 conference. Research, practice and collaboration in science education, (pp. 1178-1187). Dublin: Dublin City University.

Keselman, A., Kaufman, D. R., \& Patel, V. L. (2004). "You can exercise your way out of HIV" and other stories: The role of biological knowledge in adolescents' evaluation of myths. Science Education, 88(4), 548-573.

Leat, D., \& Nichols, A. (2000). Brains on the table: Diagnostic and formative assessment through observation. Assessment in Education: Principles, Policy \& Practice, 7(1), 103-121. https://doi.org/10.1080/713613327.

Liberman, N., \& Trope, Y. (2014). Traversing psychological distance. Trends in Cognitive Sciences, 18(7), 364-369. https://doi.org/10.1016/j.tics.2014.03.001.

Malmberg, C., \& Urbas, A. (2018). Health in school: Stress, individual responsibility and democratic politics. Cultural Studies of Science Education. https://doi.org/ 10.1007/s11422-018-9882-0.

Masic, I., Miokovic, M., \& Muhamedagic, B. (2008). Evidence based medicine New approaches and challenges. Acta Informatica Medica, 16(4), 219-225. https://doi.org/10.5455/aim.2008.16.219-225.

NGSS Lead States (2013). Next generation science standards: For states, by states. Washington, DC: National Academies Press.

Prigogine, I. (1981). From being to becoming - time and complexity in physical sciences. San Francisco: W. H. Freeman.

Roberts, D. (2007). Scientific Literacy. In S. K. Abell \& N. G. Lederman (Eds.), Handbook of research on science education (pp. 729-780). Mahwah, NJ: Lawrence Earlbaum Associates.

Sadler, T. D. (2004). Informal reasoning regarding socioscientific issues: A critical review of research. Journal of Research in Science Teaching, 41(5), 513-536. https://doi.org/10.1002/tea.20009.

Sadler, T. D., \& Zeidler, D. L. (2005). Patterns of informal reasoning in the context of Socioscientific decision making. Journal of Research in Science Teaching, 42(1), 112-138

Schlosser, M. (2015). Agency. In The Standford Encyclopedia of Philosophy (Fall 2015). Standford University Retrieved from https://plato.stanford.edu/ archives/fall2015/entries/agency/.

Schreiner, C., \& Sjøberg, S. (2004). Sowing the seeds of ROSE. Background, rationale, questionnaire development and data collection for ROSE (the relevance of science education) - a comparative study of students' views of science and science education. Acta Didactica, 4, 1-42.

Siitonen, P., Hämeen-Anttila, K., Keinonen, T., \& Vainio, K. (2014). Medicine education as a part of health education: The implementation in Finnish comprehensive schools. International Journal of Health Promotion \& Education, 52(2), 90-104. https://doi.org/10.1080/14635240.2013.871409.

Simon, U. K., Enzinger, S. M., \& Fink, A. (2017). "The evil virus cell": Students' knowledge and beliefs about viruses. PLoS One, 12(3), e0174402. https://doi. org/10.1371/journal.pone.0174402.

Sjöström, J., \& Talanquer, V. (2018). Eco-reflexive chemical thinking and action. Current Opinion in Green and Sustainable Chemistry, 13, 16-20. https://doi.org/ 10.1016/j.cogsc.2018.02.012.

Snowden, D. J., \& Boone, M. E. (2007). A leader's framework for decision making. Harvard Business Review, (Nov 2007), 1-9.

Von Neumann, J., \& Burks, A. W. (1966). Theory of self-reproducing automata. Urbana: University of Illinois Press.

Weber, B., "Life", The Stanford Encyclopedia of Philosophy (Spring 2015 Edition), E. N. Zalta (Ed.). Retrieved from https://plato.stanford.edu/archives/spr2015/ entries/life/

Wittgenstein, L. (1958). The blue and brown books. New York: Harper \& Row.

World Health Organisation. (2018). Antibiotic resistance. Retrieved 16.4.2019, from https://www.who.int/news-room/fact-sheets/detail/antibiotic-resistance

Yoon, S. A., Goh, S.-E., \& Park, M. (2017). Teaching and learning about complex systems in K-12 science education: A review of empirical studies 1995-2015. Review of Educational Research, 88(2), 003465431774609. https://doi.org/10. 3102/0034654317746090.

Zeyer, A. (2006). Medizin - Fundgrube für Integrierte Themen. In A. Zeyer, \& M. Wyss (Eds.), Interdisziplinarität im Unterricht auf der Sekundarstufe II, (pp. 6585). Zürich/Bern: Pestalozzianum/hep.

Zeyer, A. (2007). The impact of a secondary I STSE science curriculum on students, science teachers, and their schools. In ESERA conference Sweden 2007. Malmö: Malmö University. Kristianstad University. Gothenburg University. The Danish University of Education.

Zeyer, A. (2012). A win-win situation for health and science education: Seeing through the lens of a new framework model of health literacy. In A. Zeyer, \& R. Kyburz-Graber (Eds.), Science|Environment|Health. Towards a renewed pedagogy for science education. Dordrecht: Springer.

Zeyer, A. (2017). Gender, complexity, and science for all: Systemizing and its impact on motivation to learn science for different science subjects. Journal of Research in Science Teaching, 55(2), 147-171. https://doi.org/10.1002/tea.21413.

Zeyer, A., Álvaro, N., Arnold, J., Benninghaus, J. C., Hasslöf, H., Kremer, K., ... Keselman, A. (2019). Addressing complexity in science | environment | health pedagogy. In E. McLoughlin, O. Finlayson, S. Erduran, \& P. Childs (Eds.), Contributions from Science Education Research, selected papers from the ESERA 2017 conference, (pp. 153-170). Cham: Springer.

Zeyer, A., \& Dillon, J. (2014). Science|Environment|Health-Towards a reconceptualization of three critical and inter-linked areas of education. International Journal of Science Education, 36(9), 1409-1411. https://doi.org/10. 1080/09500693.2014.904993.

Zeyer, A., \& Dillon, J. (2019). The role of empathy for learning in complex Science|Environment|Health contexts. International Journal of Science Education, 41(3), 297-315. https://doi.org/10.1080/09500693.2018.1549371.

Zeyer, A., \& Kägi, S. (2010). Colorful Nature and Grey Misery: Science and Technology in an Environmental Context as Analyzed in Pictures Made by 11- to 13-Year-Old Swiss Students. Canadian Journal of Science, Mathematics and Technology Education, 10(1), 40-60. https://doi.org/10.1080/ 14926150903574304.

Zeyer, A., \& Odermatt, F. (2009). Gesundheitskompetenz (Health Literacy) Bindeglied zwischen Gesundheitsbildung und naturwissenschaftlichem Unterricht Health Literacy - a Link between Health Education and Science Education. Zeitschrift Für Didaktik Der Naturwissenschaften, 15, 265-285.

Zeyer, A., \& Roth, W. M. (2013). Post-ecological discourse in the making. Public Understanding of Science, 22(1), 33-48. https://doi.org/10.1177/ 0963662510394949

Zeyer, A., \& Sidler, T. (2015). Wie wirken sich Informationen zur HPV-Impfung auf den Impfentscheid junger Frauen aus? Prävention Und Gesundheitsförderung, 10(2), 153-158. https://doi.org/10.1007/s11553-014-0479-5.

Zohar, A., \& Ginosar, S. (1998). Lifting the taboo regarding teleology and anthropomorphism in biology education. Heretical suggestions. Science Education, 82(6), 679-697.

\section{Publisher's Note}

Springer Nature remains neutral with regard to jurisdictional claims in published maps and institutional affiliations. 